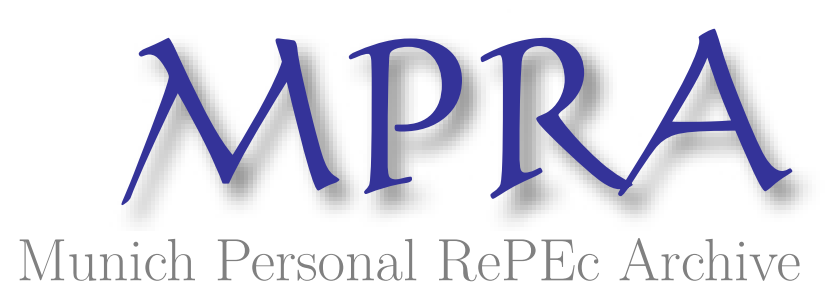

\title{
Has financial inclusion made the financial sector riskier?
}

Ozili, Peterson K

2021

Online at https://mpra.ub.uni-muenchen.de/105529/

MPRA Paper No. 105529, posted 31 Jan 2021 11:05 UTC 


\title{
Has financial inclusion made the financial sector riskier?
}

\author{
Peterson K. Ozili
}

\begin{abstract}
This paper examines whether high levels of financial inclusion is associated with greater financial risk. The findings reveal that higher account ownership is associated with greater financial risk through high nonperforming loan and high cost inefficiency in the financial sector of developed countries, advanced countries and transition economies. Increased use of debit cards, credit cards and digital finance products reduced risk in the financial sector of advanced countries and developed countries but not for transition economies and developing countries. The findings also show that the combined use of digital finance products with increased formal account ownership improves financial sector efficiency in developing countries while the combined use of credit cards with increased formal account ownership reduces insolvency risk and improves financial sector efficiency in developing countries.
\end{abstract}

Keywords: financial inclusion, digital finance, Fintech, financial technology, nonperforming loans, efficiency, financial innovation, insolvency risk, credit card, debit card, formal accounts, account ownership, black swan

JEL Classification: G0, G1, G2, G3, G21, G28, O16.

January, 2021. 


\section{Introduction}

This paper investigates whether financial inclusion increases financial risk in the formal financial sector.

Recently, the government of many countries have introduced several supply side initiatives and policies to promote financial inclusion (Demirguc-Kunt et al, 2017, Ozili, 2020a; Markose et al, 2020), but these efforts are being forestalled by weak demand for such services, particularly a declining demand for basic financial services after a few years, which gives rise to a typical "excess supply - low demand" economic problem, and the risk of loss to providers of financial services (Markose et al, 2020). Financial inclusion is a subject of growing interest among policy makers, scholars and development economists. Financial inclusion is defined as access to, and the use of, formal financial services (Allen et al, 2016). Financial risk is the potential for loss that arises from the acquisition, utilization and management of funds in firms. Examples of financial risk includes credit risk, liquidity risk, operational risk, rising cost, etc.

A growing literature show that financial inclusion has significant benefits for poor individuals and households. The benefits include access to savings instruments (Ouma et al, 2017), spending on education and healthcare (Dupas and Robinson, 2009), greater consumption (Turvey and Xiong, 2017), easy access to credit (Hendricks and Chidiac, 2011), encouraging individuals to set up their own businesses (Ozili, 2018b), low-cost financial services through digital finance apps (Ozili, 2018b), and empowering women to become financially independent (Demirgüç-Kunt, 2014). There is also evidence that the financial policies, instruments and structures created to improve access to finance have had positive effects for financial inclusion (see., Donovan, 2012; Beck et al, 2014; Ozili, 2018b). The expectation is that financial inclusion will give poor people the tools the rich have used to acquire their great wealth. When poor individuals and households have access to credit, they will feel empowered to start their own businesses and to meet their personal expenses. Financial inclusion also has other benefits to the economy such as greater financial stability, a reduction in the level of unemployment and greater economic growth (see Morgan and Pontines (2014), Ozili (2018b) and Ozili (2020a)).

Financial inclusion (i.e. opening a bank account) may translate to higher financial risk (e.g. non-performing loans) especially for account owners who take loans from lending institutions. Arguably, not all individuals open a formal bank account for the purpose of borrowing. Some individuals may open an account for transaction purposes not necessarily for borrowing. Even with transaction accounts, financial institutions expect to earn fee income from transaction costs for services rendered to accountholders as well as fee income from account maintenance fees charged to account owners. However, it is very plausible that financial institutions can lose fee income when account owners perform fewer transactions than usual. The decline in the volume of transactions will reduce the fee income to financial institutions, and the loss of fee income is also a source of financial risk, which can lead to a high cost-to-income ratio (i.e. low efficiency ratio due to low income and high cost) when the income component declines. High financial inclusion can also give rise to other risks such as the inactive user problem (Ozili, 2020a), and the misuse of credit which can make poor people worse-off than they were without credit (Smith et al, 2015). These observations in the literature suggest that some relationship exist between financial inclusion and financial risk but this relationship has not been tested in the literature. 
Using cross country data, the findings reveal that higher financial inclusion (through higher account ownership) is associated with greater financial risk (through high nonperforming loans and cost inefficiency) in the financial sector of developed countries, advanced countries and in transition economies, but the combined use of digital finance products with increased formal account ownership improves financial sector efficiency in developing countries. The implication of the findings is that the policies designed to promote financial inclusion leads to higher nonperforming loans although it improves cost efficiency when account ownership is used together with digital finance products.

This paper contributes to the literature in the following way. Firstly, this study contributes to the theoretical literature on financial risk. The literature argues that high financial risk negatively affects the performance of financial institutions (e.g. Duffie and Singleton, 2012; Bülbül et al, 2019; Psillaki et al, 2010), and financial institutions may respond to financial risk by cutting down credit supply and operating cost and such actions can affect the customers they serve (e.g. Hull, 2012; Rampini et al, 2020). Secondly, this study also contributes to the financial inclusion literature. This literature focuses mostly on the determinants and benefits of financial inclusion (e.g., Donovan, 2012; Demirguc-Kunt et al, 2017). In contrast to this literature, this paper focus on the possible consequence of financial inclusion for financial institutions which arises from the expectation that greater financial inclusion can lead to high financial risk. Therefore, this is the first paper to consider financial inclusion as a determinant of financial risk. Thirdly, by focusing on the regions of the world, some insights can be gained on the relationship between financial inclusion and financial risk for developed countries, transition countries and developing countries. Lastly, using four financial inclusion indicators, the findings test the importance of each component of financial inclusion in mitigating financial risk in developed and developing countries.

The rest of the paper is structured in the following way. Section 2 discuss the literature on financial inclusion and financial risk. Section 3 develops the hypotheses. Section 4 presents the data and methodology. Section 5 presents the empirical results. Section 6 concludes.

\section{Conceptual Framework and Literature review}

\subsection{Conceptual Framework}

The framework that describes the relationship between financial inclusion and financial risk in the formal financial sector is illustrated in figure 1. Financial inclusion affects financial risk through two main channels. In the first channel, financial inclusion allows poor individuals and households to obtain basic credit, insurance and investment products to improve their welfare (Demirguc-Kunt et al, 2017). Individuals and poor households can make good financial decisions that are welfare-improving such as taking credit that can be repaid comfortably and the effective use of available credit which reduces loan defaults (Musau et al, 2018a; Ozili, 2018b), thereby decreasing nonperforming loans and financial risk in the balance sheet of financial institutions. On the other hand, some poor individuals and households can make financial decisions that are welfare-destructing rather than welfare-improving such as the misuse of available credit which leads to over-indebtedness and loan defaults (Ozili, 2020c), thereby increasing nonperforming loans and financial risk. In the second channel, financial inclusion can transmit financial 
risk to the formal financial sector when there is low demand for basic financial services. Low demand for basic formal financial services may be caused by lack of awareness of available financial services, a general lack of interest in formal financial services, the excess documentation and paperwork required to open a formal account, financial illiteracy, poverty levels (Ramakrishnan, 2011; Martínez et al, 2013; Ozili, 2018b).

Figure 1: the nexus of financial inclusion and financial risk

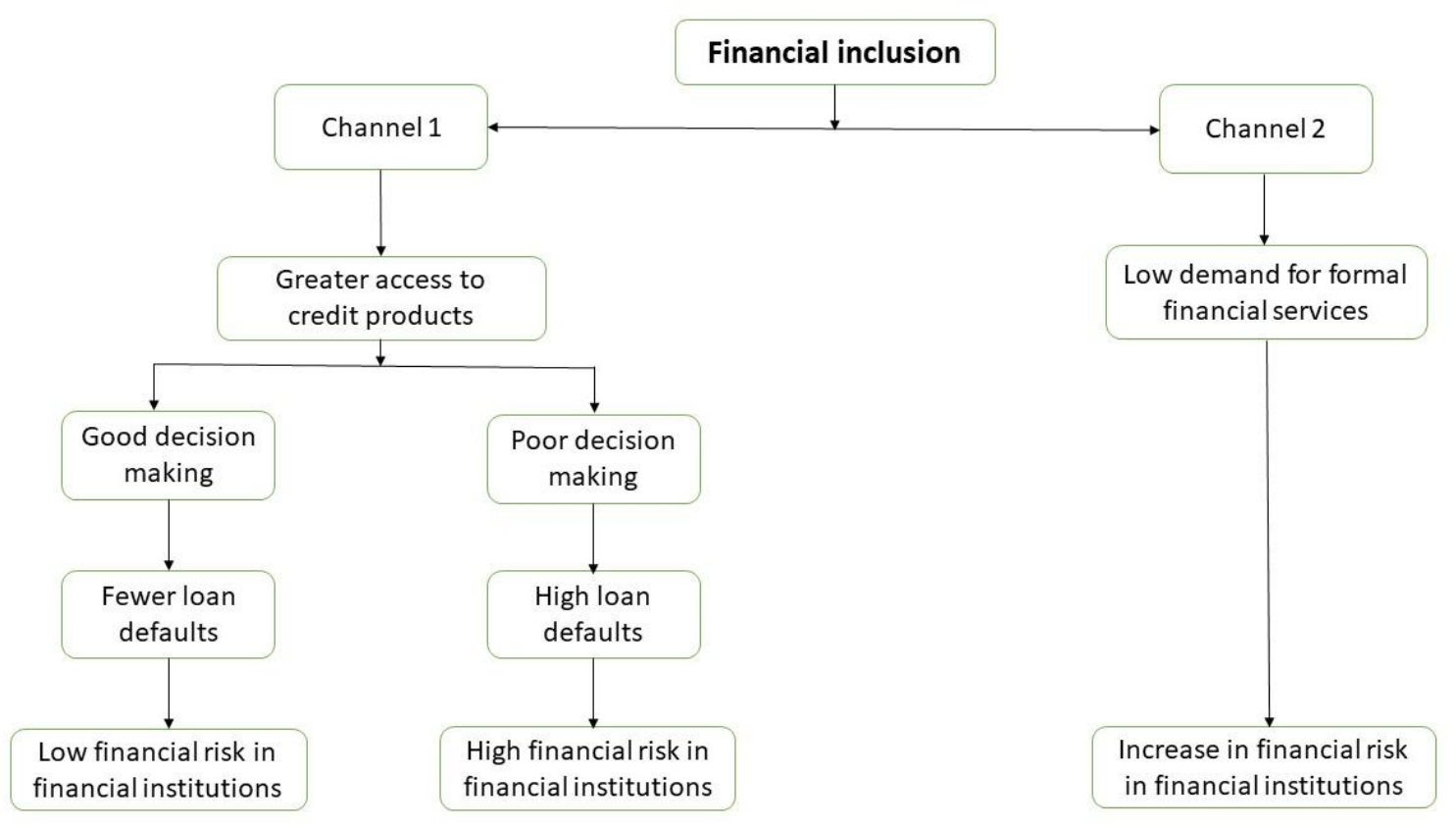

\subsection{Theory}

Some theories have been proposed to explain financial inclusion. The collaborative intervention theory states that financial inclusion can be achieved through collaborative intervention by multiple stakeholders (Ozili, 2020b). The collaborating stakeholders include Fintech companies, technological companies, financial institutions and telecommunication companies who together provide digital finance products to assist in bringing the excluded population into the formal financial sector. Similarly, Ozili (2018b) developed a theoretical framework that demonstrate how digital finance can lead to greater financial inclusion and reduce poverty levels. The framework demonstrates how the digital finance products offered by banks and Fintech businesses can bring in more people into the formal financial sector and reduce poverty levels. It also shows that direct government intervention is a viable alternative to achieve financial inclusion and for poverty reduction in the absence of digital finance products. 


\subsection{Financial inclusion}

Allen et al (2016) observe that greater ownership and use of accounts are associated with greater access to finance. They show that policies targeted to promote financial inclusion - such as requiring banks to offer basic or low-fee accounts, exempting some depositors from burdensome documentation requirements, allowing correspondent banking, and using bank accounts to make government payments - were effective in promoting financial inclusion. Park and Mercado (2015) find that financial inclusion reduces poverty levels and lowers income inequality while strong rule of law and financial regulatory oversight improves the level of financial inclusion. Sahay et al (2015) suggest that access to finance can help households and firms to protect themselves against shocks and better manage risk.

Some studies present critical perspectives on financial inclusion. De Koker and Jentzsch (2013) show that an increase in access to formal financial services does not necessarily lead to an immediate and corresponding reduction in the usage of informal financial services. Ozili (2018b) show that, although digital finance can help to improve financial inclusion, digital finance products also comes with risks such as increased cyber security risk, greater discrimination between poor and rich customers, and the onboarding of risky customers whose activities can hurt the financial system. Mehrotra and Yetman (2015) argue that banks seeking to reduce the overall riskiness of their business (de-risking), or seeking to minimize regulatory compliance costs, may turn away potential customers including poor individuals due to their high-risk profile.

\subsection{Financial risk and financial inclusion}

Morgan and Pontines (2014) find that increased access to credit to small and medium-sized enterprises (SMEs) reduces financial risk mainly by reducing non-performing loans (NPLs) and the probability of default by financial institutions. Sahay et al (2015) also show that financial inclusion can indirectly provide clients of financial firms with better risk management tools and boost their resilience to financial risk. Adasme et al (2006) show that losses on small loans may pose less systemic risk to the financial system than large losses associated with large loans. Hannig and Jansen (2010) argue that greater financial inclusion poses risks at the institutional level but these risks are not systemic in nature. García and José (2016) note that risk may rise from rapid credit growth associated with new financial inclusion institutions, instruments and from unregulated parts of the financial system. Khan (2012) show that banks that adopt the business correspondent-oriented model of financial inclusion are exposed to many risks like reputation risk, strategic risk, compliance risk and operational risk besides the risk on their asset portfolio.

Other studies relate financial inclusion to nonperforming loans. Musau et al (2018a), in their study, observed that commercial banks in Kenya pursue financial inclusion with the aim of increasing their customer base, deposits and loans accounts. But increasing financial inclusion through this channel led to increase in nonperforming loans which negatively affected the stability of commercial banks in Kenya. Morgan and Pontines (2014) show that greater financial inclusion, through increased lending to small and medium-sized enterprises (SMEs) leads to fewer non-performing loans when loans are given to SMEs rather than big corporations. Musau et al (2018b) examine the relationship between financial inclusion

and bank credit risk among Kenyan commercial banks. Financial inclusion was measured by availability, accessibility and usage indicators while bank credit risk was measured by nonperforming loans ratio. They 
find that bank availability has a negative effect on credit risk which implies that higher number of banks reduce credit risk. They also observe that bank accessibility has a positive effect on credit risk which implies that greater access to banking services leads to higher nonperforming loans.

\section{Hypothesis development}

Financial institutions issue loans to poor borrowers and small businesses in line with the prevailing financial inclusion policies with the expectation that the beneficiaries of such loan will use the loan in ways that improve their welfare and in ways that ensure that loan repayments can be made. Financial inclusion can give rise to nonperforming loans when there are misaligned incentives on the part of the beneficiaries of formal credit (Ozili, 2019; De Koker and Jentzsch, 2013; Ozili, 2018b), because poor households can obtain formal credit and use it for a different purpose than the purpose stated in their loan application forms. The beneficiaries of such loans can take up these loans and use them to engage in non-economic activities or welfare-destructing activities which will not only worsen their economic welfare but will also make it difficult to repay the loans they owe to lending institutions (Ozili, 2020c). When such loans are not repaid, they become nonperforming loans which must be written off especially when poor individuals, households and small businesses do not have collateral.

H1: Greater financial inclusion gives rise to higher financial risk through high nonperforming loans

Financial inclusion comes at a cost! Opening microfinance institutions and new bank branches to expand financial services in rural communities is costly (Gonzalez, 2007; Pollinger et al, 2007). To reach communities where the underserved population reside, financial institutions need to expand their business to rural and remote communities (Lopez and Winkler, 2018). The decision to expand financial services to rural communities will be reached after financial institutions have conducted some costbenefit analysis - even though it seem obvious that the cost may exceed the benefits for financial institutions. If the cost outweighs the benefits, financial institutions can refuse to offer financial services or choose to increase the cost of financial services to poor customers.

$\mathrm{H} 2$ : Greater financial inclusion is associated with high cost-to-income ratio in financial institutions.

\section{Data and Methodology}

\subsection{Data}

Financial inclusion data was collected from the global financial development indicators of the World bank for 79 countries that had available data for the year 2011, 2014 and 2017. Countries with incomplete data were excluded. The reason for selecting the 2011, 2014 and 2017 sample period is because financial inclusion data in the database were reported only for these three years. Data on financial sector risk was also collected from the global financial development indicator of the World bank. The data was collected for 2011, 2014 and 2017 as well, to align the financial sector risk data observations with that of the financial inclusion data, to ensure they correspond to each other. Out of the 79 countries selected, there 
are seven (7) advanced countries or most developed countries, 13 transition countries, 39 developing countries and 20 developed countries in the full sample. The descriptive statistics and the country sample description are reported in appendix $\mathrm{A} 1$ and $\mathrm{A} 2$ respectively.

\subsection{Methodology}

\subsubsection{Model Specification}

The empirical model to test the relationship between financial inclusion and financial risk is specified below:

$$
\begin{gathered}
N P L i, t=A C C i, t+D G F i, t+D C i, t+C C i, t+G D P R i, t+e \ldots \ldots \ldots \ldots \ldots \ldots \ldots \ldots \\
Z S C O R E i, t=A C C i, t+D G F i, t+D C i, t+C C i, t+G D P R i, t+e \ldots \ldots \ldots \ldots \ldots \ldots \ldots \ldots \\
E F F i, t=A C C i, t+D G F i, t+D C i, t+C C i, t+G D P R i, t+e \ldots \ldots \ldots \ldots \ldots \ldots \ldots \\
\end{gathered}
$$

Where, $\mathrm{ACC}=$ households and individuals that own an account in a formal financial institution (\% age 15+); DGF = people that use electronic payments to make payments (\% age $15+)$; DC = people that use debit cards (\% age 15+); CC = people that use credit card (\% age 15+); NPL = non-performing loans to gross loans ratio of the banking sector; EFF = cost to income ratio of the financial sector; ZSCORE = insolvency risk of the banking sector; GDPR = state of the economic cycle; $e=$ the error term; $i=$ country; $t=$ year. See variable description in Appendix A3.

\subsubsection{Model appropriateness and estimation technique}

The model in 4.2.1 estimates financial sector risk as a function of financial inclusion. Ordinary least square (OLS) regression methodology was used to estimate the effect of financial inclusion on financial risk. The ordinary least square regression model is appropriate because it captures the contribution of each financial inclusion instrument to financial sector risk. It captures the contribution of credit cards, debit cards and formal account ownership to each financial risk indicator. The regression methodology used in this paper is consistent with the approach of Markose et al (2020). The models in equations 1, 2 and 3 were estimated using OLS regression without fixed effects. The disadvantage of the OLS regression methodology is that there may be endogeneity issues - which is understandably unavoidable due to the nature of the data and the short sample period.

\subsubsection{Justification of variables}

The three measures of financial sector risk - the NPL ratio, efficiency ratio and ZSCORE - are widely used in the finance literature to measure financial sector risk. The first dependent variable is the nonperforming loans to gross loans (NPL) ratio. The NPL ratio is commonly used to measure risk in the banking sector (see Louzis et al, 2012; Ozili, 2019). A high NPL ratio will reduce the profitability of the banking sector, make the banking sector become unstable and transmit instability to the financial system (Louzis et al, 2012; Ozili, 2019). The second dependent variable is the cost to income ratio or efficiency ratio. The efficiency 
ratio or the cost-to-income ratio measures the performance of the financial sector in terms of maximizing income while reducing cost as shown in Bonin et al (2005), Margaritis and Psillaki (2007), Fiordelisi et al (2011) and Ozili (2018a). These studies argue that high levels of cost inefficiency reduce the profit of firms and signals poor management of the firm which puts financial institutions in a risky position and can limit their ability to raise additional capital to invest in profitable projects, therefore, a low cost-to-income ratio for the financial sector is desirable. The third dependent variable is the ZSCORE which is used as a proxy for a 'softer' black swan risk event. The ZSCORE measures insolvency risk in the banking sector. It measures a banking institution's distance to default or distance to bankruptcy. A high ZSCORE indicates low probability of bank failure or low insolvency risk while a low ZSCORE indicates high insolvency risk (see Lepetit and Strobel, 2013; Ozili, 2018a; Li et al, 2019).

For the explanatory variables, the first variable is the account ownership variable. Account ownership is a widely used indicator of financial inclusion in the financial inclusion literature (Demirguc-Kunt and Klapper, 2012; Allen et al, 2016). It measures the number of households and individuals that own an account in a formal financial institution. The second explanatory variable is debit card usage. Some studies argue that financial inclusion can be achieved through increased use of debit cards by households and poor individuals, and can improve their access to finance (Collard, 2007; Kapoor, 2014; Ozili, 2018b). The third explanatory variable is credit card usage. This variable has been used by Donovan (2012) and Gupte et al (2012). These studies show that higher levels of financial inclusion can be achieved using credit cards. Increased use of credit card allows poor individuals, households and small businesses to have access to overdraft loan facilities and micro loans to meet their subsistence needs and emergency expenditure (Fisher, 2016; Donovan, 2012; Gupte et al, 2012). The fourth explanatory variable is the use of digital finance products. Some studies show that financial inclusion can be achieved through increased use of digital financial products such as using electronic channels to transfer money and to perform day to day financial transactions (Gabor and Brooks, 2017; Ozili, 2018b; Ketterer, 2017; Lenka and Barik, 2018; Reiss, 2018).

\section{Results}

\subsection{Correlation analysis - full sample}

The Pearson correlation is reported in table 1 . The t-statistics are reported in single parenthesis while the p-values are reported in double parenthesis. Four indicators of financial inclusion were employed namely: account ownership (ACC), credit card usage (CC), debit card usage (DC) and use of digital finance products (DGF). Three indicators of financial risk in the financial sector were employed namely: nonperforming loans (NPL), cost-to-income ratio (EFF) or cost efficiency ratio and insolvency risk (ZSCORE). Only the significant correlation coefficients are interpreted and discussed in this section.

In the full sample, NPL is negative and significantly correlated with the DGF, CC and DC variables. This suggest that higher use of digital finance products, credit card and debit card usage are associated with lower NPLs in the full country sample. EFF is positive and significantly correlated with DGF and CC. This suggest that greater use of digital finance products and credit cards are associated with increasing cost 
inefficiency in the full country sample, and rising cost inefficiency implies higher financial sector risk. ZSCORE is positive and significantly correlated with DGF, ACC, DC and CC. This suggest that greater use of digital finance products, credit cards, debit cards and higher account ownership are associated with higher ZSCORE implying low insolvency risk in the full country sample.

Table 1: Pearson Correlation - full sample

\begin{tabular}{|c|c|c|c|c|c|c|c|c|}
\hline Variables & $\mathrm{ACC}$ & DC & DGF & $\mathrm{CC}$ & EFF & GDPR & NPL & ZSCORE \\
\hline ACC & 1.000 & & & & & & & \\
\hline & ----- & & & & & & & \\
\hline & ----- & & & & & & & \\
\hline \multirow[t]{3}{*}{ DC } & 0.92 & 1.000 & & & & & & \\
\hline & $(26.89)$ & ----- & & & & & & \\
\hline & $((0.00))$ & ----- & & & & & & \\
\hline \multirow[t]{3}{*}{ DGF } & 0.874 & 0.904 & 1.000 & & & & & \\
\hline & (20.19) & (23.70) & ----- & & & & & \\
\hline & $((0.00))$ & $((0.00))$ & ----- & & & & & \\
\hline \multirow[t]{3}{*}{$\mathrm{CC}$} & 0.761 & 0.772 & 0.838 & 1.000 & & & & \\
\hline & (13.14) & (13.58) & (17.09) & ----- & & & & \\
\hline & $((0.00))$ & $((0.00))$ & $((0.00))$ & ----- & & & & \\
\hline \multirow[t]{3}{*}{ EFF } & 0.057 & 0.068 & 0.179 & 0.206 & 1.000 & & & \\
\hline & (0.64) & (0.77) & (2.04) & (2.35) & ----- & & & \\
\hline & $((0.52))$ & $((0.44))$ & $((0.04))$ & $((0.02))$ & ----- & & & \\
\hline \multirow[t]{3}{*}{ GDPR } & -0.294 & -0.297 & -0.228 & -0.269 & -0.162 & 1.000 & & \\
\hline & $(-3.44)$ & $(-3.48)$ & $(-2.62)$ & $(-3.126)$ & $(-1.84)$ & ----- & & \\
\hline & $((0.001))$ & $((0.00))$ & $((0.01))$ & $((0.00))$ & $((0.06))$ & ----- & & \\
\hline \multirow[t]{3}{*}{ NPL } & -0.121 & -0.174 & -0.201 & -0.224 & 0.118 & -0.132 & 1.000 & \\
\hline & $(-1.37)$ & $(-1.97)$ & $(-2.30)$ & $(-2.57)$ & (1.33) & $(-1.49)$ & ----- & \\
\hline & $((0.17))$ & $((0.05))$ & $((0.02))$ & $((0.01))$ & $((0.18))$ & $((0.13))$ & ----- & \\
\hline \multirow[t]{3}{*}{ ZSCORE } & 0.177 & 0.154 & 0.246 & 0.294 & 0.030 & 0.017 & -0.29 & 1.000 \\
\hline & $(2.02)$ & (1.74) & (2.84) & (3.44) & $(0.33)$ & (0.19) & $(-3.50)$ & ---- \\
\hline & $i(0.04$ & $((0.08))$ & $((0.01))$ & $((0.00))$ & $((0.73))$ & $((0.84))$ & $((0.001))$ & ---- \\
\hline
\end{tabular}

\subsection{Regression results}

\subsubsection{Full country sample}

The sub-samples are pooled into a single full country sample. The result is report in table 2. Using NPL as the indicator of financial sector risk, the estimation result shows that ACC coefficient is positive and significant. This indicates that higher account ownership increases financial risk through higher nonperforming loans (NPLs). This result supports the findings of Ozili (2019) who show that greater use of financial development instruments increase financial risk through rising nonperforming loans. Also, the CC coefficient is negative and significant. This indicates that greater use of credit cards lead to lower 
financial risk through reduced nonperforming loans for the full sample. This result does not support the findings of Ozili (2019). The DC and GDPR coefficient are insignificant.

Using the efficiency ratio as the indicator of financial sector risk, the estimation result shows that the ACC coefficient is positive and significant. This indicates that higher formal account ownership leads to higher cost-to-income ratio in the financial sector. This implies that increased formal account ownership increases financial risk through higher cost inefficiency. This result supports Fiordelisi et al (2011) who find that high cost inefficiency leads to increased financial risk. Also, the DC and CC coefficients are negative and significant. This indicates that greater use of debit cards and credit cards lead to greater cost efficiency which lowers financial risk. The GDPR coefficient is positive and significant. This indicates that there is high cost-to-income ratio during periods of economic expansion.

Using the 'ZSCORE' ${ }^{1}$ as the indicator of financial sector risk, the estimation result shows that the DC coefficient is negative and significant at the $10 \%$ level. This indicates that greater debit card usage leads to high insolvency risk in the financial sector in the full sample. Also, the ACC coefficient is positive and significant. This indicates that higher account ownership leads to low insolvency risk which decreases financial risk. On the other hand, the CC and DGF coefficients are insignificant. The GDPR coefficient is positive and significant. This indicates that there is low insolvency risk during periods of economic expansion.

\begin{tabular}{|c|c|c|c|}
\hline & NPL & Efficiency & Insolvency risk \\
\hline Variables & $\begin{array}{l}\text { Coefficient } \\
\text { (t-statistic) }\end{array}$ & $\begin{array}{l}\text { Coefficient } \\
\text { (t-statistic) }\end{array}$ & $\begin{array}{l}\text { Coefficient } \\
\text { (t-statistic) }\end{array}$ \\
\hline ACC & $\begin{array}{c}0.294^{* * *} \\
(4.34)\end{array}$ & $\begin{array}{c}0.872^{* * *} \\
(6.03)\end{array}$ & $\begin{array}{c}0.216^{* * *} \\
(3.63)\end{array}$ \\
\hline DGF & $\begin{array}{l}-0.045 \\
(-0.55) \\
\end{array}$ & $\begin{array}{c}0.176 \\
(1.06) \\
\end{array}$ & $\begin{array}{l}-0.008 \\
(-0.12)\end{array}$ \\
\hline $\mathrm{DC}$ & $\begin{array}{l}-0.137 \\
(-1.52)\end{array}$ & $\begin{array}{c}-0.479 * * \\
(-2.55)\end{array}$ & $\begin{array}{l}-0.126^{*} \\
(-1.63)\end{array}$ \\
\hline $\mathrm{CC}$ & $\begin{array}{l}-0.149 * \\
(-1.98)\end{array}$ & $\begin{array}{c}-0.123^{* * *} \\
(-5.73)\end{array}$ & $\begin{array}{l}0.101 \\
(1.56)\end{array}$ \\
\hline GDPR & $\begin{array}{l}0.148 \\
(0.47)\end{array}$ & $\begin{array}{c}3.704^{* * *} \\
(5.73)\end{array}$ & $\begin{array}{c}1.157^{* * *} \\
(4.35)\end{array}$ \\
\hline$R^{2}(\%)$ & -2.31 & -2.51 & -9.17 \\
\hline Adjusted $\mathrm{R}^{2}(\%)$ & -5.66 & -2.60 & -12.03 \\
\hline SE of regression & 9.84 & 22.28 & 9.17 \\
\hline
\end{tabular}

\footnotetext{
${ }^{1} \mathrm{~A}$ high value of ZSCORE indicates a low likelihood of bank insolvency risk and a low value of ZSCORE indicates a high likelihood of bank insolvency risk. See Laeven and Levine (2009) and Ozili (2018a)
} 


\subsubsection{Advanced economies (most developed economies - G7 countries)}

The result is reported in table 3. Using NPL as the indicator of financial sector risk, the estimation result shows that ACC coefficient is positive and significant. This indicates that higher account ownership in advanced economies increases financial risk in the financial sector through increased high nonperforming loans. This result supports Ozili (2019) who show that higher levels of financial development increases financial risk through rising nonperforming loans. Also, the DGF coefficient is negative and significant. This indicates that greater use of digital finance products in advanced economies leads to fewer nonperforming loans (NPLs) which decreases financial risk. This result does not support the findings of Ozili (2019). The DC, CC and GDPR coefficients are insignificant.

Using the efficiency ratio as the indicator of financial sector risk, the estimation result shows that the ACC coefficient is positive and significant. This indicates that higher account ownership in advanced economies leads to higher cost-to-income ratio, which implies greater financial risk through high cost inefficiency. This result supports Fiordelisi et al (2011) who find that high cost inefficiency leads to increased financial risk. Also, the CC coefficient is negative and significant. This indicates that greater use of credit cards in advanced economies increased cost efficiency in the financial sector, which reduces financial risk. The DGF and DC coefficients are insignificant. The GDPR coefficient is negative and significant which suggest that recessions (booms) are associated with high cost inefficiency (efficiency) in advanced economies.

Using insolvency risk or the ZSCORE variable as the indicator of financial sector risk, the estimation result shows that DGF coefficient is insignificant. Also, the DC coefficient is negative and significant. This indicates that greater use of debit cards in advanced economies is associated with higher insolvency risk in the financial sector. The ACC, CC and GDPR coefficients.

\begin{tabular}{|c|c|c|c|}
\hline & NPL & Efficiency & Insolvency risk \\
\hline Variable & $\begin{array}{l}\text { Coefficient } \\
\text { (t-statistic) }\end{array}$ & $\begin{array}{l}\text { Coefficient } \\
\text { (t-statistic) }\end{array}$ & $\begin{array}{l}\text { Coefficient } \\
\text { (t-statistic) }\end{array}$ \\
\hline ACC & $\begin{array}{c}1.018^{* *} \\
(3.41)\end{array}$ & $\begin{array}{l}0.251 \\
(0.43)\end{array}$ & $\begin{array}{l}0.628 \\
(1.14)\end{array}$ \\
\hline DGF & $\begin{array}{l}-0.846^{*} \\
(-2.27)\end{array}$ & $\begin{array}{l}0.884 \\
(1.18)\end{array}$ & $\begin{array}{l}0.436 \\
(0.61)\end{array}$ \\
\hline $\mathrm{DC}$ & $\begin{array}{l}-0.194 \\
(-1.02)\end{array}$ & $\begin{array}{l}-0.058 \\
(-0.13)\end{array}$ & $\begin{array}{c}-0.991 * * \\
(-2.37)\end{array}$ \\
\hline $\mathrm{CC}$ & $\begin{array}{l}-0.150 \\
(-1.81)\end{array}$ & $\begin{array}{l}-0.381^{*} \\
(-2.24)\end{array}$ & $\begin{array}{l}-0.048 \\
(-0.29)\end{array}$ \\
\hline GDPR & $\begin{array}{l}3.087 \\
(1.29)\end{array}$ & $\begin{array}{l}-4.581 \\
(-0.96)\end{array}$ & $\begin{array}{l}3.685 \\
(0.81)\end{array}$ \\
\hline $\mathrm{R}^{2}(\%)$ & 80.63 & 57.46 & 45.04 \\
\hline Adjusted $\mathrm{R}^{2}(\%)$ & 67.71 & 38.56 & 20.62 \\
\hline S.E of regression & 2.85 & 6.72 & 6.39 \\
\hline
\end{tabular}




\subsubsection{Transition economies (economies in transition)}

The result is reported in table 4. Using NPL as the indicator of financial sector risk, the estimation result shows that all the financial inclusion variables are insignificant to draw any meaningful conclusion.

Using the efficiency ratio as the indicator of financial sector risk, the estimation result shows that ACC coefficient is positive and significant at the $5 \%$ level. This indicates that higher account ownership in transition economies leads to higher cost-to-income ratio in the financial sector, which implies increased financial risk through higher cost inefficiency. This result supports Fiordelisi et al (2011) who find that high cost inefficiency leads to increased financial risk. Also, the DGF coefficient is negative and significant. This indicates that greater use of digital finance products in transition economies leads to lower financial risk through a reduction in the cost-to-income ratio. This result supports the argument of Lerner and Tufano (2011). The GDPR coefficient is positive and significant, which suggest that economic booms are associated with high cost inefficiency in transition economies. The CC and DC coefficients are insignificant.

Using the ZSCORE as the indicator of financial sector risk, the estimation result shows that the ACC coefficient is positive and significant at the $1 \%$ level. This indicates that higher use of account ownership in transition economies leads to low insolvency risk in the financial sector. Also, the DGF coefficient is negative and significant at the $10 \%$ level. This indicates that higher use of digital finance products in transition economies is associated with high insolvency risk. The CC, DC and GDPR coefficients are not significant.

\begin{tabular}{|c|c|c|c|}
\hline & NPL & Efficiency & Insolvency risk \\
\hline Variables & $\begin{array}{l}\text { Coefficient } \\
\text { (t-statistic) }\end{array}$ & $\begin{array}{l}\text { Coefficient } \\
\text { (t-statistic) }\end{array}$ & $\begin{array}{l}\text { Coefficient } \\
\text { (t-statistic) } \\
\end{array}$ \\
\hline ACC & $\begin{array}{l}-0.153 \\
(-0.41)\end{array}$ & $\begin{array}{c}1.167^{* *} \\
(2.34)\end{array}$ & $\begin{array}{c}0.472^{* * *} \\
(2.89)\end{array}$ \\
\hline DGF & $\begin{array}{l}-0.219 \\
(-0.65)\end{array}$ & $\begin{array}{c}-0.943^{* *} \\
(-2.13)\end{array}$ & $\begin{array}{c}-0.285^{*} \\
(-1.97)\end{array}$ \\
\hline DC & $\begin{array}{l}0.408 \\
(0.66)\end{array}$ & $\begin{array}{l}0.171 \\
(0.24)\end{array}$ & $\begin{array}{l}-0.095 \\
(-0.42)\end{array}$ \\
\hline CC & $\begin{array}{l}0.837 \\
(1.71) \\
\end{array}$ & $\begin{array}{l}0.709 \\
(1.01) \\
\end{array}$ & $\begin{array}{l}-0.359 \\
(-1.57) \\
\end{array}$ \\
\hline GDPR & $\begin{array}{l}0.635 \\
(0.82) \\
\end{array}$ & $\begin{array}{c}2.586^{* *} \\
(2.20)\end{array}$ & $\begin{array}{l}1.375 \\
(0.18)\end{array}$ \\
\hline $\mathrm{R}^{2}(\%)$ & 12.53 & -87.56 & 6.37 \\
\hline Adjusted $\mathrm{R}^{2}(\%)$ & -0.81 & -1.23 & -11.46 \\
\hline SE of regression & 11.77 & 17.94 & 5.87 \\
\hline
\end{tabular}




\subsubsection{Developing countries}

The result is reported in table 5. Using NPL as the indicator of financial sector risk, the estimation result shows that only the GDPR coefficient is positive and significant. This indicates that developing countries have higher nonperforming loans during periods of economic prosperity. The ACC, DGF, DC and CC coefficients are insignificant.

Using the efficiency ratio as the indicator of financial sector risk, the estimation result shows that the GDPR coefficient is positive and significant. This indicates that developing countries have higher cost inefficiency during periods of economic prosperity. The ACC, DGF, DC and CC coefficients are insignificant.

Using the ZSCORE as the indicator of financial sector risk, the estimation result shows that the ACC coefficient is positive and significant at the $5 \%$ level. This indicates that higher account ownership in developing countries leads to low insolvency risk in the financial sector of developing countries. The GDPR coefficient is positive and significant. This indicates that developing countries have low insolvency risk during periods of economic prosperity. The DGF, DC and CC coefficients are insignificant.

\begin{tabular}{|c|c|c|c|}
\hline & NPL & Efficiency ratio & Insolvency risk \\
\hline Variables & $\begin{array}{l}\text { Coefficient } \\
\text { (t-statistic) }\end{array}$ & $\begin{array}{l}\text { Coefficient } \\
\text { (t-statistic) }\end{array}$ & $\begin{array}{l}\text { Coefficient } \\
\text { (t-statistic) }\end{array}$ \\
\hline ACC & $\begin{array}{l}-0.012 \\
(-0.21)\end{array}$ & $\begin{array}{l}0.388 \\
(1.63)\end{array}$ & $\begin{array}{c}0.217 * * * \\
(2.29)\end{array}$ \\
\hline DGF & $\begin{array}{l}0.024 \\
(0.39)\end{array}$ & $\begin{array}{l}0.394 \\
(1.61)\end{array}$ & $\begin{array}{l}0.048 \\
(0.49)\end{array}$ \\
\hline$D C$ & $\begin{array}{l}-0.031 \\
(-0.46)\end{array}$ & $\begin{array}{l}-0.263 \\
(-0.97)\end{array}$ & $\begin{array}{l}-0.050 \\
(-0.46)\end{array}$ \\
\hline $\mathrm{CC}$ & $\begin{array}{l}-0.037 \\
(-0.55)\end{array}$ & $\begin{array}{l}-0.006 \\
(-0.02)\end{array}$ & $\begin{array}{l}-0.057 \\
(-0.52)\end{array}$ \\
\hline GDPR & $\begin{array}{c}1.417^{* * *} \\
(5.09)\end{array}$ & $\begin{array}{c}5.954^{* * *} \\
(5.57)\end{array}$ & $\begin{array}{c}1.122^{* *} \\
(2.62)\end{array}$ \\
\hline $\mathrm{R}^{2}(\%)$ & 6.36 & -2.97 & -21.27 \\
\hline Adjusted $\mathrm{R}^{2}(\%)$ & 0.33 & -3.19 & -27.91 \\
\hline SE of Regression & 5.79 & 25.49 & 10.22 \\
\hline
\end{tabular}

\subsubsection{Developed countries}

The result is reported in table 6 . Using NPL as the dependent variable, the estimation result shows that the ACC coefficient is positive and significant. This indicates that higher account ownership increases financial sector risk through higher nonperforming loans (NPLS) in developed countries. This result supports Ozili (2019) who show that greater use of financial development instruments increases nonperforming loans. Also, the DC, CC and DGF coefficients are negative and significant. This indicates that greater use of debit cards, credit cards and digital finance products in developed countries lead to lower financial risk through reduced nonperforming loans (NPLs). The GDPR coefficient is insignificant. 
Using the efficiency ratio as the indicator of risk in the financial sector, the estimation result shows that the ACC coefficient is positive and significant. This indicates that higher account ownership in developed countries leads to higher cost-to-income ratio, which implies increased financial risk through higher cost inefficiency. This result supports the findings of Fiordelisi et al (2011). The DGF, DC, CC and GDPR coefficients are insignificant.

Using the ZSCORE as the indicator of financial sector risk, the estimation result shows that the CC coefficient is positive and significant at the $1 \%$ level. This indicates that greater use of credit cards in developed countries leads to low insolvency risk in the financial sector of developed countries. The ACC, DGF, DC and GDPR coefficients are insignificant.

\begin{tabular}{|c|c|c|c|}
\hline & NPL & Efficiency & Insolvency risk \\
\hline Variables & $\begin{array}{l}\text { Coefficient } \\
\text { (t-statistic) }\end{array}$ & $\begin{array}{l}\text { Coefficient } \\
\text { (t-statistic) }\end{array}$ & $\begin{array}{l}\text { Coefficient } \\
\text { (t-statistic) }\end{array}$ \\
\hline ACC & $\begin{array}{c}0.883^{* * *} \\
(8.07) \\
\end{array}$ & $\begin{array}{c}0.841^{* * *} \\
(5.49) \\
\end{array}$ & $\begin{array}{l}0.103 \\
(1.03) \\
\end{array}$ \\
\hline DGF & $\begin{array}{c}-0.306^{* *} \\
(-2.13)\end{array}$ & $\begin{array}{l}-0.027 \\
(-0.13)\end{array}$ & $\begin{array}{l}0.139 \\
(1.06)\end{array}$ \\
\hline DC & $\begin{array}{c}-0.511^{* * *} \\
(-2.83)\end{array}$ & $\begin{array}{l}-0.119 \\
(-0.48)\end{array}$ & $\begin{array}{l}-0.197 \\
(-1.23)\end{array}$ \\
\hline $\mathrm{CC}$ & $\begin{array}{c}-0.163^{*} \\
(-1.87) \\
\end{array}$ & $\begin{array}{l}-0.145 \\
(-1.24) \\
\end{array}$ & $\begin{array}{c}0.226^{* * *} \\
(2.97) \\
\end{array}$ \\
\hline GDPR & $\begin{array}{l}-0.048 \\
(-0.09)\end{array}$ & $\begin{array}{l}-0.431 \\
(-0.58)\end{array}$ & $\begin{array}{l}0.256 \\
(0.53)\end{array}$ \\
\hline $\mathrm{R}^{2}(\%)$ & 63.20 & -12.89 & 35.29 \\
\hline Adjusted $\mathrm{R}^{2}$ (\%) & 59.42 & -22.11 & 30.01 \\
\hline SE of regression & 7.46 & 11.09 & 7.23 \\
\hline
\end{tabular}

\subsection{Additional Analyses}

This section tests the effect of the financial inclusion indicators on financial sector risk using interaction analysis. The variables of interest are the interaction variables. Only the significant coefficient of the interaction terms are discussed. The model is re-specified below.

$$
\begin{gathered}
R I S K i, t=A C C i, t+D G F i, t+C C i, t+D C i, t+A C C * D G F+A C C * C C i, t+A C C * D C i, t \\
+G D P R+e
\end{gathered}
$$

Where, $A C C=$ formal account ownership, $C C=$ credit card usage, $D C=$ debit card usage, $D G F=$ use of digital finance products, GDPR = state of economic cycle, and RISK = a vector of the dependent variables (that is, the NPL ratio, efficiency ratio and ZSCORE).

Using the ZSCORE as a measure of financial sector risk in table 7, the estimation result shows that the ACC*DGF coefficient is positive and significantly related to ZSCORE for developed countries only. This indicates that an increase in the use of digital finance products and formal account ownership is associated with low insolvency risk. This finding does not support Ozili (2018a). Also, the ACC*DC coefficient is 
negative and significantly related to the ZSCORE particularly for developed countries, developing countries and for the full-country sample. This implies that greater use of debit cards and higher account ownership are associated with high insolvency risk in developed and developing countries. Also, the ACC*CC coefficient is positive and significantly related to the ZSCORE for developing countries. This implies that greater use of credit cards and higher formal account ownership are significantly associated with low insolvency risk for developing countries.

\begin{tabular}{|c|c|c|c|c|c|}
\hline & Full sample & $\begin{array}{c}\text { Developed } \\
\text { country }\end{array}$ & $\begin{array}{c}\text { Developing } \\
\text { country }\end{array}$ & $\begin{array}{l}\text { Transition } \\
\text { countries }\end{array}$ & $\begin{array}{l}\text { Advanced } \\
\text { countries }\end{array}$ \\
\hline Variables & $\begin{array}{l}\text { Coefficient } \\
\text { (t-statistic) }\end{array}$ & $\begin{array}{l}\text { Coefficient } \\
\text { (t-statistic) }\end{array}$ & $\begin{array}{l}\text { Coefficient } \\
\text { (t-statistic) }\end{array}$ & $\begin{array}{l}\text { Coefficient } \\
\text { (t-statistic) }\end{array}$ & $\begin{array}{l}\text { Coefficient } \\
\text { (t-statistic) }\end{array}$ \\
\hline ACC & $\begin{array}{c}0.147^{* * *} \\
(2.46)\end{array}$ & $\begin{array}{l}0.201 \\
(1.56)\end{array}$ & $\begin{array}{c}0.174^{*} \\
(1.99)\end{array}$ & $\begin{array}{c}0.354^{*} \\
(2.06)\end{array}$ & $\begin{array}{l}0.932 \\
(1.33)\end{array}$ \\
\hline DGF & $\begin{array}{l}-0.104 \\
(-0.70)\end{array}$ & $\begin{array}{c}-3.101^{* *} \\
(-2.27)\end{array}$ & $\begin{array}{l}-0.099 \\
(-0.47)\end{array}$ & $\begin{array}{l}0.237 \\
(0.47)\end{array}$ & $\begin{array}{l}1.097 \\
(0.03)\end{array}$ \\
\hline DC & $\begin{array}{c}0.837^{* * *} \\
(4.01) \\
\end{array}$ & $\begin{array}{l}2.359 \\
(2.14) \\
\end{array}$ & $\begin{array}{c}0.999 * * \\
(3.81)\end{array}$ & $\begin{array}{l}-0.205 \\
(-0.38) \\
\end{array}$ & $\begin{array}{l}-8.777 \\
(-0.27) \\
\end{array}$ \\
\hline CC & $\begin{array}{c}-1.164^{* * *} \\
(-3.99)\end{array}$ & $\begin{array}{l}0.684 \\
(0.50)\end{array}$ & $\begin{array}{c}-1.242^{* * *} \\
(-2.75)\end{array}$ & $\begin{array}{l}0.434 \\
(0.42)\end{array}$ & $\begin{array}{l}10.572 \\
(1.45)\end{array}$ \\
\hline ACC*DGF & $\begin{array}{l}0.002 \\
(0.86) \\
\end{array}$ & $\begin{array}{c}0.037^{* *} \\
(2.39) \\
\end{array}$ & $\begin{array}{l}0.002 \\
(0.41) \\
\end{array}$ & $\begin{array}{l}-0.006 \\
(-0.65) \\
\end{array}$ & $\begin{array}{l}-0.014 \\
(-0.04) \\
\end{array}$ \\
\hline$A C C * D C$ & $\begin{array}{c}-0.011^{* * *} \\
(-4.32)\end{array}$ & $\begin{array}{c}-0.031^{* *} \\
(-2.34)\end{array}$ & $\begin{array}{c}-0.013^{* * *} \\
(-3.77)\end{array}$ & $\begin{array}{l}0.005 \\
(0.50)\end{array}$ & $\begin{array}{l}0.084 \\
(0.25)\end{array}$ \\
\hline $\mathrm{ACC} * \mathrm{CC}$ & $\begin{array}{c}0.015^{* * *} \\
(4.43) \\
\end{array}$ & $\begin{array}{l}-0.005 \\
(-0.36) \\
\end{array}$ & $\begin{array}{c}0.015^{* *} \\
(2.33) \\
\end{array}$ & $\begin{array}{l}-0.018 \\
(-0.90) \\
\end{array}$ & $\begin{array}{l}-0.110 \\
(-1.47) \\
\end{array}$ \\
\hline GDPR & $\begin{array}{c}0.676^{* *} \\
(2.47) \\
\end{array}$ & $\begin{array}{l}0.549 \\
(1.10)\end{array}$ & $\begin{array}{l}0.525 \\
(1.18) \\
\end{array}$ & $\begin{array}{l}-0.027 \\
(-/ 06)\end{array}$ & $\begin{array}{l}6.103 \\
(1.11) \\
\end{array}$ \\
\hline$R^{2}(\%)$ & 6.12 & 42.54 & 6.91 & 23.50 & 65.20 \\
\hline Adjusted $\mathrm{R}^{2}(\%)$ & 2.39 & 33.80 & $-2 . .39$ & -6.24 & 24.60 \\
\hline SE of regression & 8.42 & 7.03 & 9.14 & 5.74 & 6.23 \\
\hline
\end{tabular}

Using the NPL ratio as a measure of financial sector risk in table 8, the estimation result shows that the $A C{ }^{*} D G F, A C C^{*} D C$ and $A C C^{*} C C$ coefficients are not significant for all the country groups. The GDPR coefficient is positive and significant for developing countries category which suggest that economic booms are associated with high nonperforming loans in developing countries. 


\begin{tabular}{|c|c|c|c|c|c|}
\hline \multicolumn{6}{|c|}{ Table 8: Joint effect of financial inclusion on NPL ratio } \\
\hline & Full sample & $\begin{array}{c}\text { Developed } \\
\text { country }\end{array}$ & $\begin{array}{c}\text { Developing } \\
\text { country }\end{array}$ & $\begin{array}{c}\text { Transition } \\
\text { countries }\end{array}$ & $\begin{array}{l}\text { Advanced } \\
\text { countries }\end{array}$ \\
\hline Variables & $\begin{array}{l}\text { Coefficient } \\
\text { (t-statistic) }\end{array}$ & $\begin{array}{l}\text { Coefficient } \\
\text { (t-statistic) }\end{array}$ & $\begin{array}{l}\text { Coefficient } \\
\text { (t-statistic) }\end{array}$ & $\begin{array}{l}\text { Coefficient } \\
\text { (t-statistic) }\end{array}$ & $\begin{array}{l}\text { Coefficient } \\
\text { (t-statistic) }\end{array}$ \\
\hline ACC & $\begin{array}{c}0.263^{* * *} \\
(3.59)\end{array}$ & $\begin{array}{c}0.933^{* * *} \\
(6.18)\end{array}$ & $\begin{array}{l}0.011 \\
(0.19)\end{array}$ & $\begin{array}{l}-0.308 \\
(-0.72)\end{array}$ & $\begin{array}{l}0.742 \\
(1.36)\end{array}$ \\
\hline DGF & $\begin{array}{l}0.254 \\
(1.19) \\
\end{array}$ & $\begin{array}{l}-0.898 \\
(-0.56) \\
\end{array}$ & $\begin{array}{l}0.227 \\
(1.36) \\
\end{array}$ & $\begin{array}{l}0.666 \\
(0.52) \\
\end{array}$ & $\begin{array}{l}-2.454 \\
(-0.08) \\
\end{array}$ \\
\hline $\mathrm{DC}$ & $\begin{array}{l}-0.388 \\
(-1.27)\end{array}$ & $\begin{array}{l}-0.085 \\
(-0.07)\end{array}$ & $\begin{array}{l}-0.204 \\
(-0.96)\end{array}$ & $\begin{array}{l}0.668 \\
(0.43)\end{array}$ & $\begin{array}{l}4.419 \\
(0.14)\end{array}$ \\
\hline CC & $\begin{array}{l}0.259 \\
(0.68)\end{array}$ & $\begin{array}{l}-0.374 \\
(-0.23)\end{array}$ & $\begin{array}{l}-0.015 \\
(-0.05)\end{array}$ & $\begin{array}{l}-1.646 \\
(-0.68)\end{array}$ & $\begin{array}{l}-3.733 \\
(-0.72)\end{array}$ \\
\hline ACC*DGF & $\begin{array}{l}-0.004 \\
(-1.29)\end{array}$ & $\begin{array}{l}0.007 \\
(0.37)\end{array}$ & $\begin{array}{l}-0.004 \\
(-1.21)\end{array}$ & $\begin{array}{l}-0.020 \\
(-0.89)\end{array}$ & $\begin{array}{l}0.019 \\
(0.06)\end{array}$ \\
\hline$A C C * D D$ & $\begin{array}{l}0.004 \\
(1.02)\end{array}$ & $\begin{array}{l}-0.005 \\
(-0.36)\end{array}$ & $\begin{array}{c}0.003 \\
(1.004)\end{array}$ & $\begin{array}{l}0.002 \\
(0.09)\end{array}$ & $\begin{array}{l}-0.047 \\
(-0.15)\end{array}$ \\
\hline $\mathrm{ACC}^{*} \mathrm{CC}$ & $\begin{array}{l}-0.004 \\
(-0.86)\end{array}$ & $\begin{array}{l}0.002 \\
(0.12)\end{array}$ & $\begin{array}{l}0.001 \\
(0.20)\end{array}$ & $\begin{array}{l}0.048 \\
(1.06)\end{array}$ & $\begin{array}{l}0.037 \\
(0.71)\end{array}$ \\
\hline GDPR & $\begin{array}{l}-0.029 \\
(-0.08) \\
\end{array}$ & $\begin{array}{l}0.029 \\
(0.05) \\
\end{array}$ & $\begin{array}{c}1.248^{* * *} \\
(3.73) \\
\end{array}$ & $\begin{array}{l}0.813 \\
(0.76) \\
\end{array}$ & $\begin{array}{l}1.868 \\
(0.53) \\
\end{array}$ \\
\hline & & & & & \\
\hline$R^{2}(\%)$ & 1.80 & 63.48 & -9.89 & 23.81 & 85.94 \\
\hline Adjusted $\mathrm{R}^{2}(\%)$ & -3.97 & 56.38 & -20.07 & -14.28 & 64.85 \\
\hline SE of Regression & 9.75 & 7.74 & 5.83 & 12.11 & 3.28 \\
\hline
\end{tabular}

Using the cost efficiency ratio as a measure of financial sector risk in table 9, the estimation result shows that the ACC*DGF coefficient is negative and significantly related to the cost efficiency ratio for advanced countries which indicates that greater use of digital finance products and account ownership leads to greater cost efficiency particularly in developing countries. The ACC*CC coefficient is positive and significantly related to the cost efficiency ratio for developing countries, which indicates that greater use of credit cards and formal account ownership leads to higher cost-to-income ratio particularly in developing countries. 


\begin{tabular}{|c|c|c|c|c|c|}
\hline \multicolumn{6}{|c|}{ Table 9: Joint effect of financial inclusion on cost efficiency } \\
\hline & Full sample & $\begin{array}{c}\text { Developed } \\
\text { country }\end{array}$ & $\begin{array}{c}\text { Developing } \\
\text { country }\end{array}$ & $\begin{array}{c}\text { Transition } \\
\text { countries }\end{array}$ & $\begin{array}{c}\text { Advanced } \\
\text { countries }\end{array}$ \\
\hline Variables & $\begin{array}{c}\text { Coefficient } \\
\text { (t-statistic) }\end{array}$ & $\begin{array}{c}\text { Coefficient } \\
\text { (t-statistic) }\end{array}$ & $\begin{array}{c}\text { Coefficient } \\
\text { (t-statistic) }\end{array}$ & $\begin{array}{c}\text { Coefficient } \\
\text { (t-statistic) }\end{array}$ & $\begin{array}{c}\text { Coefficient } \\
\text { (t-statistic) }\end{array}$ \\
\hline ACC & $0.488^{* * *}$ & $0.548^{* * *}$ & $0.587^{* * *}$ & 0.860 & $1.446^{* *}$ \\
& $(3.80)$ & $(2.88)$ & $(3.26)$ & $(1.67)$ & $(2.87)$ \\
\hline DGF & $1.449^{* * *}$ & 1.584 & $2.122^{* * *}$ & -0.393 & -39.499 \\
& $(4.53)$ & $(0.79)$ & $(4.85)$ & $(-0.26)$ & $(-1.63)$ \\
\hline DC & 0.363 & -0.113 & 0.196 & 1.179 & 32.985 \\
& $(0.81)$ & $(-0.07)$ & $(0.36)$ & $(0.73)$ & $(1.41)$ \\
\hline CC & 0.006 & -0.352 & -0.937 & 1.886 & 7.932 \\
& $(0.01)$ & $(-0.16)$ & $(-1.01)$ & $(0.61)$ & $(1.51)$ \\
\hline ACC*DGF & $-0.017^{* * *}$ & -0.016 & $-0.037^{* * *}$ & 0.002 & 0.412 \\
& $(-3.29)$ & $(-0.69)$ & $(-4.15)$ & $(0.08)$ & $(1.65)$ \\
\hline ACC*DC & -0.004 & 0.002 & -0.0001 & -0.011 & -0.351 \\
& $(-0.72)$ & $(0.08)$ & $(-0.02)$ & $(-0.39)$ & $(-1.45)$ \\
\hline ACC*CC & 0.004 & 0.004 & $0.026^{*}$ & -0.035 & -0.085 \\
& $(0.59)$ & $(0.18)$ & $(1.92)$ & $(-0.58)$ & $(-1.59)$ \\
\hline GDPR & $1.611^{* * *}$ & -0.981 & $2.507^{* * *}$ & 0.725 & 0.158 \\
& $(2.74)$ & $(-1.33)$ & $(2.74)$ & $(0.51)$ & $(0.04)$ \\
\hline & & & & & \\
\hline$R^{2}$ (\%) & -126.62 & 7.52 & $-107 . .5$ & -46.98 & 87.37 \\
\hline Adjusted R $\left.{ }^{2} \%\right)$ & -137.20 & -6.56 & -127.9 & -1.04 & 72.66 \\
\hline SE of Regression & 18.07 & 10.37 & 18.79 & 17.15 & 4.48 \\
\hline$* * * * *, *$ denotes statistical significance at the 1\%,5\% and 10\% level. & & \\
\hline
\end{tabular}

To summarize, the combined use of digital finance products with increased formal account ownership improves financial sector efficiency in developing countries. Also, the joint use of credit cards with increased formal account ownership reduces insolvency risk and improves financial sector efficiency in developing countries.

\section{Conclusion}

This study examined the relationship between financial inclusion and financial risk, to determine whether the financial sector has become riskier during the financial inclusion revolution.

The findings reveal that higher formal account ownership increased financial risk through high nonperforming loans and cost inefficiency in the financial sector of developed countries, advanced countries and transition economies, while increased use of debit cards, credit cards and digital finance products reduced risk in the financial sectors of advanced countries and developed countries but not for transition countries and developing countries. In the interaction analyses, the findings reveal that the use of digital finance products with increased formal account ownership improved financial sector efficiency in developing countries. Also, the use of credit cards with increased formal account ownership reduced insolvency risk and improved financial sector efficiency in developing countries. 
The findings have several implications for policy and financial regulation. One, policy makers in developed and developing countries should take steps to increase financial inclusion using several drivers of financial inclusion. Policy makers should ensure that barriers to formal account ownership in financial institutions are removed. Policy makers should also ensure that financial institutions provide sufficient card products and digital finance products to all individuals and households especially to poor individuals and households. Two, policy makers should increase financial regulation and adopt a supervisory framework that ensures that financial institutions have strong risk controls to reduce high nonperforming loans arising from the loan accounts of poor individuals, households and businesses. This will help to mitigate the effect of financial risk on financial institutions. Three, the evidence that financial inclusion is negatively associated with financial sector risk calls for caution to policy makers when expanding financial services. Reckless expansion of financial services should be discouraged. Priority should be given to welfareenhancing financial inclusion for poor individuals, households and businesses. At the same time, financial regulators should be mindful of the high cost borne by financial institutions in offering basic financial services. Policy makers may need to offer supply side subsidies to financial institutions to help them cope

with the rising cost of financial services as well as other emerging financial risks caused by greater financial inclusion and the expansion of financial services to poor individuals, households and businesses.

Future research should identify other types of financial risk that are associated with greater financial inclusion. Future research should also examine whether risk in the financial sector is amplified to a greater extent by demand-side determinants of financial inclusion.

\section{Reference}

Adasme, Osvaldo, Giovanni Majnoni, and Myriam Uribe. (2006). "Access and Risk: Friends or Foes? Lessons from Chile." World Bank Policy Research Working Paper 4003. Washington, D.C.: World Bank.

Allen, F., A. Demirguc-Kunt, L. Klapper, and M. S. M. Peria. (2016). The foundations of financial inclusion: Understanding ownership and use of formal accounts. Journal of Financial Intermediation

Beck, T., Senbet, L., \& Simbanegavi, W. (2014). Financial inclusion and innovation in Africa: An overview. Journal of African Economies, 24(suppl_1), i3-i11.

Bonin, J. P., Hasan, I., \& Wachtel, P. (2005). Bank performance, efficiency and ownership in transition countries. Journal of banking \& finance, 29(1), 31-53.

Bülbül, D., Hakenes, H., \& Lambert, C. (2019). What influences banks' choice of credit risk management practices? Theory and evidence. Journal of Financial Stability, 40, 1-14.

Collard, S. (2007). Toward financial inclusion in the UK: Progress and challenges. Public Money and Management, 27(1), 13-20.

De Koker, L., \& Jentzsch, N. (2013). Financial inclusion and financial integrity: Aligned incentives? World development, 44, 267-280. 
Demirguc-Kunt, A., \& Klapper, L. (2012). Measuring financial inclusion: The global findex database. The World Bank. Policy Research Working Paper 6025.

Demirgüç-Kunt, A. (2014). Presidential address: Financial inclusion. Atlantic Economic Journal, 42(4), 349-356.

Demirguc-Kunt, A., Klapper, L., \& Singer, D. (2017). Financial inclusion and inclusive growth: A review of recent empirical evidence. The World Bank.

Donovan, K. (2012). Mobile money for financial inclusion. Information and Communications for development, 61(1), 61-73.

Duffie, D., \& Singleton, K. J. (2012). Credit risk: pricing, measurement, and management. Princeton university press.

Dupas, R., \& Robinson, J. (2009). Savings Constraints and Microenterprise Development: Evidence from a Field Experiment. NBER Working Paper Series, (14693).

Fiordelisi, F., Marques-Ibanez, D., \& Molyneux, P. (2011). Efficiency and risk in European banking. Journal of banking \& finance, 35(5), 1315-1326.

Fisher, P. J. (2016). Differences in credit card use between White and Hispanic households. Journal of Financial Counseling and Planning, 27(2), 199-211.

Gabor, D., \& Brooks, S. (2017). The digital revolution in financial inclusion: international development in the fintech era. New Political Economy, 22(4), 423-436.

García, M. J. R., \& José, M. (2016). Can financial inclusion and financial stability go hand in hand. Economic Issues, 21(2), 81-103.

Gonzalez, A. (2007). Efficiency drivers of microfinance institutions (MFIs): The case of operating costs. Microbanking bulletin, (15).

Gupte, R., Venkataramani, B., \& Gupta, D. (2012). Computation off financial inclusion index for India. Procedia-Social and Behavioral Sciences, 37, 133-149.

Hannig, A., \& Jansen, S. (2010). Financial inclusion and financial stability: Current policy issues.

Hendricks, L., \& Chidiac, S. (2011). Village savings and loans: A pathway to financial inclusion for Africa's poorest households. Enterprise Development and Microfinance, 22(2), 134-146.

Hull, J. (2012). Risk management and financial institutions, Web Site (Vol. 733). John Wiley \& Sons.

Kapoor, A. (2014). Financial inclusion and the future of the Indian economy. Futures, 56, 35-42.

Ketterer, J. A. (2017). Digital finance: new times, new challenges, new opportunities. Inter-American Development Bank.

Khan, H. R. (2012). Issues and challenges in financial inclusion: Policies, partnerships, processes and products. Korea, 18(250.29), 84-17. 
Laeven, L., \& Levine, R. (2009). Bank governance, regulation and risk taking. Journal of financial economics, 93(2), 259-275.

Lenka, S. K., \& Barik, R. (2018). Has expansion of mobile phone and internet use spurred financial inclusion in the SAARC countries? Financial Innovation, 4(1), 5.

Lepetit, L., \& Strobel, F. (2013). Bank insolvency risk and time-varying Z-score measures. Journal of International Financial Markets, Institutions and Money, 25, 73-87.

Lerner, J., \& Tufano, P. (2011). The consequences of financial innovation: a counterfactual research agenda. Annu. Rev. Financ. Econ., 3(1), 41-85.

Li, X., Tripe, D., Malone, C., \& Smith, D. (2019). Measuring systemic risk contribution: the Leave-One-Out z-score method. Finance Research Letters, 101316.

Lopez, T., \& Winkler, A. (2018). The challenge of rural financial inclusion-evidence from microfinance. Applied Economics, 50(14), 1555-1577.

Louzis, D. P., Vouldis, A. T., \& Metaxas, V. L. (2012). Macroeconomic and bank-specific determinants of non-performing loans in Greece: A comparative study of mortgage, business and consumer loan portfolios. Journal of Banking \& Finance, 36(4), 1012-1027.

Margaritis, D., \& Psillaki, M. (2007). Capital structure and firm efficiency. Journal of Business Finance \& Accounting, 34(9-10), 1447-1469.

Markose, S. M., Arun, T., \& Ozili, P. K. (2020, March). Financial Inclusion, At What Cost? Quantification of Economic Viability of A Supply Side Roll Out. In At What Cost. Working Paper.

Martínez, C. H., Hidalgo, X. P., \& Tuesta, D. (2013). Demand factors that influence financial inclusion in Mexico: analysis of the barriers based on the ENIF survey. BBVA Bank, BBVA Research Working Paper, 119.

Mehrotra, A. N., \& Yetman, J. (2015). Financial inclusion-issues for central banks. BIS Quarterly Review March. Basel, Switzerland.

Morgan, P., \& Pontines, V. (2014). Financial stability and financial inclusion.

Musau, S., Muathe, S., \& Mwangi, L. (2018a). Financial inclusion, bank competitiveness and credit risk of commercial banks in Kenya. International Journal of Financial Research, 9(1), 203.

Musau, S., Muathe, S., \& Mwangi, L. (2018b). Financial inclusion, GDP and credit risk of commercial banks in kenya. International Journal of Economics and Finance, 10(3), 181-195.

Ouma, S. A., Odongo, T. M., \& Were, M. (2017). Mobile financial services and financial inclusion: Is it a boon for savings mobilization? Review of development finance, 7(1), 29-35.

Ozili, P. K. (2018a). Banking stability determinants in Africa. International Journal of Managerial Finance, 14(4), 462-483. 
Ozili, P. K. (2018b). Impact of digital finance on financial inclusion and stability. Borsa Istanbul Review, 18(4), 329-340.

Ozili, P. K. (2019). Non-performing loans and financial development: new evidence. The Journal of Risk Finance, 20(1), 59-81.

Ozili, P. K. (2020a, January). Financial inclusion research around the world: A review. In Forum for Social Economics (pp. 1-23). Routledge.

Ozili, P. K. (2020b). Theories of financial inclusion. Available at SSRN 3526548.

Ozili, P. K. (2020c). Financial inclusion: a strong critique. Available at SSRN 3584574.

Park, C. Y., \& Mercado, R. (2015). Financial inclusion, poverty, and income inequality in developing Asia. Asian Development Bank Economics Working Paper Series, (426).

Pollinger, J. J., Outhwaite, J., \& Cordero-Guzmán, H. (2007). The question of sustainability for microfinance institutions. Journal of Small Business Management, 45(1), 23-41.

Psillaki, M., Tsolas, I. E., \& Margaritis, D. (2010). Evaluation of credit risk based on firm performance. European journal of operational research, 201(3), 873-881.

Ramakrishnan, D. (2011). Financial Literacy-The Demand Side of Financial Inclusion. Available at SSRN 1958417.

Rampini, A. A., Viswanathan, S., \& Vuillemey, G. (2020). Risk management in financial institutions. The Journal of Finance, 75(2), 591-637.

Reiss, D. G. (2018). Is money going digital? An alternative perspective on the current hype. Financial Innovation, 4(1), 1-6.

Sahay, R., Čihák, M., N'Diaye, P. M. B. P., Barajas, A., Mitra, S., Kyobe, A., ... \& Yousefi, S. R. (2015). Financial inclusion: can it meet multiple macroeconomic goals? (No. 15/17). Washington, DC: International Monetary Fund.

Smith, T. E., Richards, K. V., Shelton, V. M., \& Malespin, T. S. (2015). Sirens' call: Understanding poor financial decision making and credit card misuse. Journal of Human Behavior in the Social Environment, 25(8), 897-906.

Turvey, C. G., \& Xiong, X. (2017). Financial inclusion, financial education, and e-commerce in rural china. Agribusiness, 33(2), 279-285. 


\section{Appendix}

\begin{tabular}{|c|c|c|c|c|c|c|c|c|c|}
\hline \multicolumn{10}{|c|}{ A1: Summary of Sample Statistics } \\
\hline All Countries & Statistic & ACC & $\mathrm{CC}$ & DC & DGF & EFF & GDPR & NPL & ZSCORE \\
\hline & Mean & 59.81 & 22.04 & 44.81 & 48.58 & 56.77 & 3.64 & 7.62 & 13.97 \\
\hline & Median & 62.90 & 13.47 & 39.71 & 43.27 & 56.42 & 3.51 & 4.26 & 12.78 \\
\hline & Std. Dev. & 30.68 & 21.81 & 30.34 & 30.64 & 12.07 & 2.75 & 8.53 & 8.55 \\
\hline & Observations & 237 & 237 & 237 & 158 & 237 & 237 & 206 & 237 \\
\hline \multirow[t]{5}{*}{ Developing } & & ACC & $\mathrm{CC}$ & DC & DGF & EFF & GDPR & NPL & ZSCORE \\
\hline & Mean & 42.94 & 11.28 & 26.87 & 31.73 & 55.07 & 4.55 & 5.90 & 15.37 \\
\hline & Median & 36.65 & 4.51 & 22.06 & 27.65 & 54.48 & 4.55 & 3.25 & 14.58 \\
\hline & Std. Dev. & 25.26 & 15.46 & 20.57 & 20.65 & 12.04 & 2.52 & 6.31 & 9.02 \\
\hline & Observations & 117 & 117 & 117 & 78 & 117 & 117 & 100 & 117 \\
\hline \multirow[t]{5}{*}{ Transition } & & ACC & $\mathrm{CC}$ & DC & DGF & EFF & GDPR & NPL & ZSCORE \\
\hline & Mean & 44.41 & 10.95 & 30.54 & 30.36 & 58.54 & 3.54 & 11.81 & 9.30 \\
\hline & Median & 43.78 & 9.50 & 29.64 & 31.78 & 56.20 & 4.10 & 10.04 & 7.61 \\
\hline & Std. Dev. & 20.45 & 7.39 & 16.21 & 17.29 & 14.70 & 3.03 & 9.86 & 5.22 \\
\hline & Observations & 39 & 39 & 39 & 26 & 39 & 39 & 35 & 39 \\
\hline \multirow[t]{5}{*}{ Developed } & & ACC & $\mathrm{CC}$ & $\mathrm{DC}$ & DGF & EFF & GDPR & NPL & ZSCORE \\
\hline & Mean & 91.59 & 42.94 & 77.58 & 81.69 & 58.36 & 2.37 & 7.97 & 14.20 \\
\hline & Median & 96.31 & 43.02 & 84.60 & 89.76 & 58.75 & 2.26 & 4.09 & 12.61 \\
\hline & Std. Dev. & 9.96 & 18.93 & 17.88 & 18.02 & 10.40 & 2.42 & 9.81 & 8.43 \\
\hline & Observations & 81 & 81 & 81 & 54 & 81 & 81 & 71 & 81 \\
\hline \multirow[t]{5}{*}{ Advanced } & & ACC & $\mathrm{CC}$ & DC & DGF & EFF & GDPR & NPL & ZSCORE \\
\hline & Mean & 94.71 & 55.38 & 79.02 & 89.27 & 66.90 & 1.89 & 3.68 & 17.18 \\
\hline & Median & 96.58 & 60.13 & 86.98 & 89.76 & 65.64 & 2.19 & 2.39 & 15.05 \\
\hline & Std. Dev. & 6.38 & 14.96 & 20.46 & 8.06 & 8.68 & 1.046 & 4.39 & 7.01 \\
\hline & Observations & 21 & 21 & 21 & 14 & 21 & 21 & 18 & 21 \\
\hline & & & & & & & & & \\
\hline
\end{tabular}


A2: Country Sample

\begin{tabular}{|c|c|c|}
\hline Category & $\begin{array}{l}\text { Number of } \\
\text { countries }\end{array}$ & Name of country \\
\hline Full sample & 79 & $\begin{array}{l}\text { Austria, Belgium, Denmark, Finland, France, Germany, } \\
\text { Greece, Ireland, Italy, Luxembourg, Netherlands, Portugal, } \\
\text { Spain, United kingdom, Bulgaria, Croatia, Cyprus, Estonia, } \\
\text { Hungary, Lithuania, Malta, Poland, Australia, Canada, Japan, } \\
\text { New Zealand, United states, Algeria, Egypt, Mauritius, } \\
\text { Mauritania, Cameroun, Chad, Kenya, Tanzania, Uganda, } \\
\text { Rwanda, Madagascar, South Africa, Zambia, Ghana, Nigeria, } \\
\text { Sierra Leone, Senegal, China, Indonesia, Malaysia, } \\
\text { Philippine, Singapore, Thailand, Vietnam, Pakistan, India, Sri } \\
\text { Lanka, Israel, Jordan, Saudi Arabia, Turkey, Costa Rica, } \\
\text { Honduras, Mexico, Argentina, Chile, Colombia, Peru, } \\
\text { Uruguay, Albania, Bosnia and Herzegovina, Serbia, Armenia, } \\
\text { Azerbaijan, Belarus, Georgia, Kazakhstan, Moldova, Russia, } \\
\text { Tajikistan, Ukraine and Uzbekistan. }\end{array}$ \\
\hline Advanced countries & 7 & $\begin{array}{l}\text { Canada, Japan, France, Germany, Italy, United Kingdom and } \\
\text { United States. }\end{array}$ \\
\hline Developed countries & 27 & $\begin{array}{l}\text { Austria, Belgium, Denmark, Finland, France, Germany, } \\
\text { Greece, Ireland, Italy, Luxembourg, Netherlands, Portugal, } \\
\text { Spain, United Kingdom, Bulgaria, Croatia, Cyprus, Estonia, } \\
\text { Hungary, Lithuania, Malta, Poland, Australia, Canada, Japan, } \\
\text { New Zealand and United states. }\end{array}$ \\
\hline Transition economies & 13 & $\begin{array}{l}\text { Albania, Bosnia and Herzegovina, Serbia, Armenia, } \\
\text { Azerbaijan, Belarus, Georgia, Kazakhstan, Moldova, Russia, } \\
\text { Tajikistan, Ukraine and Uzbekistan. }\end{array}$ \\
\hline Developing countries & 39 & $\begin{array}{l}\text { Algeria, Egypt, Mauritius, Mauritania, Cameroun, Chad, } \\
\text { Kenya, Tanzania, Uganda, Rwanda, Madagascar, South } \\
\text { Africa, Zambia, Ghana, Nigeria, Sierra Leone, Senegal, china, } \\
\text { Indonesia, Malaysia, Philippine, Singapore, Thailand, } \\
\text { Vietnam, Pakistan, India, Sri Lanka, Israel, Jordan, Saudi } \\
\text { Arabia, Turkey, Costa Rica, Honduras, Mexico, Argentina, } \\
\text { Chile, Colombia, Peru and Uruguay }\end{array}$ \\
\hline
\end{tabular}


A3: Variable description and sources

\begin{tabular}{|l|l|l|}
\hline \multicolumn{3}{|c|}{ Variable description and sources } \\
\hline Variables & Description & Sources \\
\hline ACC & $\begin{array}{l}\text { households and individuals that own an account in a } \\
\text { formal financial institution (\% age 15+). }\end{array}$ & $\begin{array}{l}\text { global financial development } \\
\text { indicator of the World bank }\end{array}$ \\
\hline DGF & $\begin{array}{l}\text { households and individuals that use electronic } \\
\text { payments to make payments (\% age 15+). }\end{array}$ & $\begin{array}{l}\text { global financial development } \\
\text { indicator of the World bank }\end{array}$ \\
\hline DC & $\begin{array}{l}\text { households and individuals that use debit cards (\% } \\
\text { age 15+). }\end{array}$ & $\begin{array}{l}\text { global financial development } \\
\text { indicator of the World bank }\end{array}$ \\
\hline CC & $\begin{array}{l}\text { households and individuals that use credit card (\% } \\
\text { age 15+). }\end{array}$ & $\begin{array}{l}\text { global financial development } \\
\text { indicator of the World bank }\end{array}$ \\
\hline NPL & $\begin{array}{l}\text { non-performing loans to gross loans ratio of the } \\
\text { banking sector. }\end{array}$ & $\begin{array}{l}\text { global financial development } \\
\text { indicator of the World bank }\end{array}$ \\
\hline EFF & cost to income ratio of the financial sector. & $\begin{array}{l}\text { global financial development } \\
\text { indicator of the World bank }\end{array}$ \\
\hline ZSCORE & insolvency risk of the banking sector. & $\begin{array}{l}\text { global financial development } \\
\text { indicator of the World bank }\end{array}$ \\
\hline GDPR & growth in real gross domestic product & World Economic Forum \\
\hline
\end{tabular}

